\title{
Chemical composition and evaluation of the antibacterial and Cytotoxic activities of the essential oil from the leaves of Myracrodruon urundeuva
}

\author{
Ítalo Diego Rebouças de Araújo ${ }^{*}$, Nayara Coriolano de Aquino ${ }^{2}$, Andreza Conceição Véras de Aguiar Guerra ${ }^{3}$, \\ Renato Ferreira de Almeida Júnior ${ }^{4}$, Renata Mendonça Araújo ${ }^{5}$, Raimundo Fernandes de Araújo Júnior ${ }^{3}$, \\ Kléber Juvenal Silva Farias ${ }^{6}$, José Veríssimo Fernandes ${ }^{1}$ and Vânia Sousa Andrade
}

\begin{abstract}
Background: This study evaluated the in vitro activity of essential oil extracted from the leaves of Myracrodruon urundeuva. Methods: The oil was obtained by hydro-distillation and characterized by Gas Chromatography coupled to Mass Spectrometry (GC-MS) and Gas Chromatography with Flame lonization Detector (GC-FID). The antibacterial activity was evaluated by the broth microdilution technique and the MIF was determined by using growth indicator CTT (2,3,5triphenyl-tetrazolium) and CBM in BHI agar. The oil's cytotoxicity was evaluated in HeLa, HEK-293, and Vero E6 cells using MTT, 3- (4,5-dimethylthiazol-2-yl) -2,5-diphenyl tetrazolium.

Results: The oil showed chemical markers, including a-pinene (87.85\%), trans-caryophyllene (1.57\%), limonene (1.49\%) and $\beta$-pinene (1.42\%), and activity against all strains: Staphylococcus aureus (MIC $=M B C=0.22 \mathrm{mg} / \mathrm{mL}$ ), Staphylococcus epidermidis ( $\mathrm{MIC}=0.11 \mathrm{mg} / \mathrm{mL}$ and $\mathrm{MBC}=0.22 \mathrm{mg} / \mathrm{mL}$ ), Escherichia coli $(\mathrm{MIC}=0.88 \mathrm{mg} / \mathrm{mL}$ and $\mathrm{MBC}=1.75 \mathrm{mg} / \mathrm{mL})$, Pseudomonas aeruginosa $(\mathrm{MIC}=\mathrm{MBC}=7 \mathrm{mg} / \mathrm{mL}$ ) and Salmonella Enteritidis $(\mathrm{MIC}=\mathrm{MBC}=0.44 \mathrm{mg} / \mathrm{mL})$. In vitro cytotoxicity tests showed that the oil is not toxic and has slight antitumor activity.
\end{abstract}

Conclusions: We conclude that the M. urundeuva oil results are promising, with prospects of being pharmacologically viable.

Keywords: Myracrodruon urundeuva, Bactericidal activity, Minimum inhibitory concentration, Chemical characterization, Essential oil, Cytotoxicity

\section{Background}

From the earliest times, medicinal plants have been widely used as natural drugs in the treatment, curing and prevention of disease [1]. Among these are bacterial diseases [2-4]. While facing increasing bacterial resistance against routinely used traditional and synthetic antibiotics for the treatment of microbial diseases [5-7], we find that research in plant-based natural products to elucidate new therapies from novel antibacterial agents has grown significantly $[8,9]$. Studies report

\footnotetext{
* Correspondence: italo_diego1989@hotmail.com

${ }^{1}$ Centro de Biociências (CB), Departamento de Microbiologia e Parasitologia, Universidade Federal do Rio Grande do Norte (UFRN), Natal, RN 59072-970, Brazil

Full list of author information is available at the end of the article
}

that certain natural antibacterials, when given with standard antibiotics, are even more effective in synergy than the standard drug alone [10-12]. In the cells of resistant pathogens, these naturally occurring molecules supposedly reach different targets than the known antibiotics do.

Among various natural substances with antimicrobial potential, essential oils have been highlighted. These generally consist of a mixture of natural volatile chemical compounds, such as monoterpenes and sesquiterpenes, and their oxygenated derivatives [13]. Such compounds comprise the secondary metabolites of aromatic plants, which are considered to be natural remedies $[14,15]$ with antimicrobial activity [16-20]. They may therefore be an alternative to overcome the increasing antibacterial 
resistance of pathogens. Essential oils are also being investigated by some researchers for their anti-cancer potential $[21,22]$.

Among the aromatic plants whose essential oils are extracted, a promising candidate is an endemic savanna tree, widely distributed in Brazil, that belongs to the family Anacardiaceae: Myracrodruon urundeuva (Aroeira of the backwoods) [23]. This plant has been noted for its antimicrobial potential, which was evidenced when molecules obtained from crude extracts of $M$. urundeuva were found to have antibacterial and antifungal properties [24-27]. Additionally, other studies indicate antiparasitic [28], analgesic and anti-inflammatory properties [29], encouraging research on the possible uses for this substance in herbal medicine.

The essential oil extracted from the leaves of $M$. urundeuva comprises a blend of terpenes which have not yet been fully elucidated. Based on these premises, the main objective of this study was to evaluate the in vitro antimicrobial and cytotoxic activities of essential oil extracted from the leaves of M. urundeuva, which is typically grown in northeastern Brazil.

\section{Methods}

\section{Plant material and essential oil extraction}

Leaves of $M$. urundeuva were collected from ten (10) specimens grown in the Núcleo de Pesquisa em Agricultura Urbana (NEPAU), Department of Plant Science, Ceará Federal University (UFC), Fortaleza, Ceará, Brazil. The leaves were collected with the aid of pruning shears at four different points in the tree canopy and then were mixed in paper bags to form composite samples. After being cut and mixed, they were packed in a drying oven at $75{ }^{\circ} \mathrm{C}$. The dry weight of the collected plant material was $100 \mathrm{~kg}$. The voucher specimen (No. 48904) was deposited at the Prisco Bezerra Herbarium of the Department of Biology, Ceará Federal University. To extract the essential oil, M. urundeuva leaves were hydrodistilled in a Clevenger-type apparatus, as adapted by Gottlieb [30]. In this process, fresh $M$. urundeuva leaves were placed in a $5 \mathrm{~L}$ flask, into which $2 \mathrm{~L}$ of distilled water were added and the system was boiled for $2 \mathrm{~h}$, until it reached $80{ }^{\circ} \mathrm{C}$, to afford yellowish oils by steam stripping. These were dried over $\mathrm{Na}_{2} \mathrm{SO}_{4}$, stored in sealed glass vials, and preserved under refrigeration before analysis. The yield of the oils $(0.02 \% \mathrm{w} / \mathrm{w})$ was calculated from the fresh weight of the plant materials. The oily extract, weighed on a precision scale, revealed a concentration of $0.9 \mathrm{~g} / \mathrm{mL}$.

\section{Identification of essential oil constituents}

Essential oils were analyzed by Gas Chromatography coupled to Mass Spectrometry (GC-MS) and Gas Chromatography with a Flame Ionization Detector (GC-FID).
The same chromatographic conditions were used for GCMS (Shimadzu GCMS-QP2010-Plus) and GC-FID (GC20100FI) analysis. The oil was analyzed using an RTx-5 infused-silica capillary column $(30 \mathrm{~m} \times 0,25 \mathrm{~mm}$ i.d., $0.25 \mu \mathrm{m}$ film thickness); the splitless injection used an injector temperature of $220{ }^{\circ} \mathrm{C}$, and the column was programmed to run from 60 to $240{ }^{\circ} \mathrm{C}$ at $3{ }^{\circ} \mathrm{C} / \mathrm{min}$ and held isothermal for $7 \mathrm{~min}$. The flow rate was $1.0 \mathrm{~mL} \mathrm{~min}{ }^{-1}$, and helium and hydrogen $\left(\mathrm{H}_{2}\right)$ were used as the gas carriers for the GC-MS and GC-FID analyses, respectively. The interface temperature of the GC-MS was $240{ }^{\circ} \mathrm{C}$ and mass spectra were recorded from 30 to $450 \mathrm{~m} / z$, at a scan interval of $0.5 \mathrm{~s}$ and an electron impact ionization voltage of $70 \mathrm{eV}$. Individual components were identified by comparing the acquired mass spectrum with reference data using the Wiley L-Built library and by comparing their retention indices with a commercially available database (NIST 2.0) and the indices described by [31]. Additional identification was obtained by using a compound's experimental Kovat's retention index (RI), as calculated from a C9-C24 n-alkanes series.

\section{Microbial isolates}

The tested microorganisms were maintained at $8{ }^{\circ} \mathrm{C}$ and included Staphylococcus aureus (ATCC 25923), Staphylococcus epidermidis (ATCC 12228), Escherichia coli (ATCC 25922), Pseudomonas aeruginosa (ATCC 27853) and Salmonella Enteritidis (INCQS 500258). Inoculates were prepared from growth on BHI (Brain Heart Infusion) agar at $37^{\circ} \mathrm{C} / 24 \mathrm{~h}$; Colonies were added in sterile $0.9 \%$ saline and adjusted to $0.5 \mathrm{McF}$ arland, which is equivalent to $10^{8}$ colony-forming units per $\mathrm{mL}\left(10^{8} \mathrm{CFU} / \mathrm{mL}\right)$.

\section{Antibacterial activity}

The antibacterial activity of the oil was assessed quantitatively by the broth microdilution technique in 96 well microplates [32]. The test sample $(\mathrm{T})$ was diluted serially at the following concentrations: $450 ; 225 ; 112.5 ; 56 ; 28$; $14 ; 7 ; 3.52 ; 1.76 ; 0.88 ; 0.44 ; 0.22 ; 0.11 ; 0.055 ; 0.028$ and $0.014 \mathrm{mg} / \mathrm{mL}$. The positive control (PC) used serial dilutions of gentamicin (Gentamisan - SANTISA ${ }^{\circ}$ ) at a concentration of $0.016 \mathrm{mg} / \mathrm{mL}$ or $16 \mu \mathrm{g} / \mathrm{mL}$. As a negative control (NC), an aqueous solution of $5 \%$ Tween 80 was used. We then added $20 \mu \mathrm{L}$ of the inoculum solution to each of the wells. In the growth control (GC), only the inoculum was added. The microplate was incubated at $37{ }^{\circ} \mathrm{C} / 24 \mathrm{~h}$ to determine the minimum inhibitory concentration (MIC). All tests were performed in triplicate.

\section{Determination of the minimum inhibitory concentration (MIC)}

To determine the MIC, $20 \mu \mathrm{L}$ of CTT (2,3,5-triphenyltetrazolium chloride) $0.5 \%$ solution was applied to each well to reveal bacterial growth. The MIC readings were 
performed after incubation at $37{ }^{\circ} \mathrm{C}$ for a further $2 \mathrm{~h}$ and were defined as the lowest concentrations of essential oil visually inhibiting microbial growth [33].

\section{Determination of the minimum bactericidal concentration (MBC)}

The bactericidal activity of the test oil was measured after reading the MIC by seeding the contents of the micro-titer wells into $\mathrm{BHI}$ agar. The most representative wells of the T, PC, NC and GC groups were chosen. From each selected well, $8 \mu \mathrm{L}$ was seeded in specific regions numbered on the back of the Petri dishes, which were then incubated at $37^{\circ} \mathrm{C}$. After $24 \mathrm{~h}$ of incubation, readings were carried out to determine the bactericidal action of the oil. The MBC was considered the lowest concentration that totally prevented microbial growth in BHI agar.

\section{Cytotoxicity assay}

Having shown antibacterial activity, Myracrodruon urundeuva essential oil was evaluated for its cytotoxicity to Vero E6 (renal epithelial Cercopithecus aethiops), HeLa (human cervical adenocarcinoma) and HEK-293 (human kidney embryonic) cell lines obtained from the Culture Collection of the Federal University of Rio de Janeiro, and cultured in Dulbecco's modified Eagle's medium (DMEM) supplemented with $10 \%$ fetal bovine serum (FBS), and $1 \%$ antibiotic (penicillin/streptomycin). The cells were maintained in an incubator at $37{ }^{\circ} \mathrm{C}$ in an atmosphere of $5 \% \mathrm{CO}_{2}$. To assess the viability and proliferation rate of the cell lines in the presence of the oil, a colorimetric assay based on the tetrazolium salt MTT (3- (4,5-dimethylthiazol-2-yl) -2,5-diphenyltetrazolium bromide) (Sigma-Aldrich, Germany) was performed as described by Mosmann (1983) [34]. This technique evaluates the metabolic activity of the cells by quantifying the MTT reduction by NADPH and NADH-associated dehydrogenases that results in the production of formazan crystals within the cells, giving the characteristic coloration to the medium. For this study, cells were placed in 96 well plates with a density of $5 \times 10^{3}$ cells/well. After $24 \mathrm{~h}$ under the culture conditions, serum deprivation was performed, and, after another $24 \mathrm{~h}$, we applied $M$. urundeuva essential oil at concentrations of $0.275 \mathrm{mg} / \mathrm{mL}, 0.55 \mathrm{mg} / \mathrm{mL}, 1.1 \mathrm{mg} / \mathrm{mL}, 2.2 \mathrm{mg} / \mathrm{mL}$ and $4.4 \mathrm{mg} / \mathrm{mL}$ to the cell strains. After the cells were treated for $24 \mathrm{~h}$ or $48 \mathrm{~h}, 100 \mu \mathrm{L} /$ well of MTT $(5 \mathrm{mg} / \mathrm{mL})$ was added and incubated for $4 \mathrm{~h}$. After this, the medium was removed and $100 \mu \mathrm{L}$ of ethanol was added to each well. The plates were shaken and the absorbance obtained in a microplate reader (Epoch - BioTek Instruments Inc., USA) at $570 \mathrm{~nm}$, using Gen5 Data Analysis version 2.0 software (BioTek Instruments Inc., USA). The growth control consisted only of cell culture in the culture medium. The assays were assessed in triplicate and the cell viability percentage was calculated as follows:

$$
C V \%=(\text { Abs sample } / \text { Abs growth control }) \times 100
$$

\section{Statistical analysis}

To compare the cell viability of the Vero E6, HeLa and HEK-293 cells lines between $24 \mathrm{~h}$ and $48 \mathrm{~h}$, a Wilcoxon test (R-3.1.1 Software) was performed on the data obtained from the above formula.

\section{Results}

\section{Chemical characterization of the essential oil of $M$. urundeuva}

During the chemical characterization of $M$. urundeuva leaf essential oil, the presence of four major chemical markers was detected with intraspecific variability: $\alpha$-pinene $(87.85 \%)$ as the major constituent, trans-caryophyllene (1.57\%), limonene (1.49\%) and $\beta$-pinene (1.42\%). The constituents were identified by mass spectrometry (GC-MS and GC/FID), shown in Table 1.

\section{MIC and MBC determination}

The MIC and MBC results are shown in Table 2. The controls validated the tests. The positive control (PC) showed no bacterial growth at higher concentrations, demonstrating the effectiveness of gentamicin as a positive control in the test, since the antibiotic's inhibitory effect on the bacteria occurred up to a concentration of $0.004 \mathrm{mg} / \mathrm{mL}(4 \mu \mathrm{g} / \mathrm{mL})$, with equivalence between the $\mathrm{MIC}$ and MBC. Bacterial growth occurred in all assays for both the negative control $(\mathrm{NC})$ and for the growth control (GC), confirming the non-bacterial inhibition of Tween 80 and the viability of the strains used and demonstrating the antibacterial effect of $M$. urundeuva oil.

\section{Cell-based toxicity results}

In the cell viability assay for the Vero E6 line, it was shown in the first reading after $24 \mathrm{~h}$ of exposure that there was toxic activity at concentrations of $4.4 \mathrm{mg} / \mathrm{mL}$ and $2.2 \mathrm{mg} /$ $\mathrm{mL}$ of oil, inducing cell death at $93.91 \%$ and $2.32 \%$, respectively. However, the lower oil concentrations of $1.1 \mathrm{mg} / \mathrm{ml}, 0.55 \mathrm{mg} / \mathrm{ml}$, and $0.275 \mathrm{mg} / \mathrm{ml} \mathrm{did} \mathrm{not} \mathrm{affect}$ the viability of the cells. In the second reading, after $48 \mathrm{~h}$ of exposure, cell toxicity occurred only at the highest concentration, $4.4 \mathrm{mg} / \mathrm{mL}$, which killed $94.26 \%$ of cells. For the other concentrations of $2.2 \mathrm{mg} / \mathrm{mL}, 1.1 \mathrm{mg} / \mathrm{mL}$, $0.55 \mathrm{mg} / \mathrm{mL}$ and $0.275 \mathrm{mg} / \mathrm{mL}$, cell viability was not affected by the oil. However, statistically, there was no significant difference between the cellular viability values at $24 \mathrm{~h}$ and $48 \mathrm{~h}(p=0.7972(p>0.05)$, indicating that the 
Table 1 Essential oil components identified by GC-MS and GC/ FID

\begin{tabular}{lllll}
\hline$\#$ & Compound & ${ }^{a} \mathrm{Rl}$ & ${ }^{\mathrm{b}} \mathrm{Rlc}$ & Essential Oil (\%) \\
\hline 1 & a-Pinene & 939 & 958 & 87.85 \\
2 & Canfene & 946 & 964 & 0.28 \\
3 & $\beta$-Pinene & 979 & 982 & 1.42 \\
4 & Myrcene & 990 & 991 & 1.82 \\
5 & S-3-Carene & 1011 & 1006 & 0.22 \\
6 & Limonene & 1029 & 1022 & 1.49 \\
7 & Eucalyptol & 1031 & 1024 & 0.43 \\
8 & Terpinolene & 1088 & 1074 & 0.43 \\
9 & trans-Cariofilene & 1419 & 1419 & 1.57 \\
10 & Aromadendrene & 1441 & 1438 & 0.57 \\
11 & Viridiflorene & 1496 & 1495 & 0.18 \\
12 & Viridiflorol & 1592 & 1582 & 0.63 \\
& Hydrocarbons monoterpenes & & & 93.51 \\
& oxygenated monoterpenes & & & 0.43 \\
& hydrocarbons sesquiterpenes & & & 2.32 \\
Oxygenated sesquiterpenes & & & 0.63 \\
Total identified & & & 96.89 \\
\hline
\end{tabular}

${ }^{\mathrm{a}} \mathrm{RI}$ : Kovat's retention index

${ }^{\mathrm{b}} \mathrm{RIc}$ : Kovats Indices calculated through the equation $\mathrm{Ric}=24.07 \mathrm{Tr}+818$

oil only inhibits Vero E6 cells at the highest concentration, $4.4 \mathrm{mg} / \mathrm{mL}$. The results are shown in Fig. 1.

After treating HeLa strain for $24 \mathrm{~h}$, we observed that the largest $M$. urundeuva oil concentrations had a greater inhibitory effect on tumor cell proliferation. Accordingly, the oil showed inhibitions from $11 \%$ to $21 \%$ between the doses of $1.1 \mathrm{mg} / \mathrm{mL}$ and $4.4 \mathrm{mg} / \mathrm{mL}$. After treatment for $48 \mathrm{~h}$, concentrations of $2.2 \mathrm{mg} / \mathrm{mL}$ and $4.4 \mathrm{mg} / \mathrm{mL}$ showed a greater inhibition of proliferation $-32.4 \%$ and $44.3 \%$, respectively. This suggests that, although there was no statistically significant difference between the viabilities observed after $24 \mathrm{~h}$ and $48 \mathrm{~h}(p=0.8085 ; p>0.05)$, the oil had notable antitumor activity after $24 \mathrm{~h}$ that intensified over longer exposure times, as shown in the $48 \mathrm{~h}$ reading, which slightly decreased cell viability at all concentrations (Fig. 2).

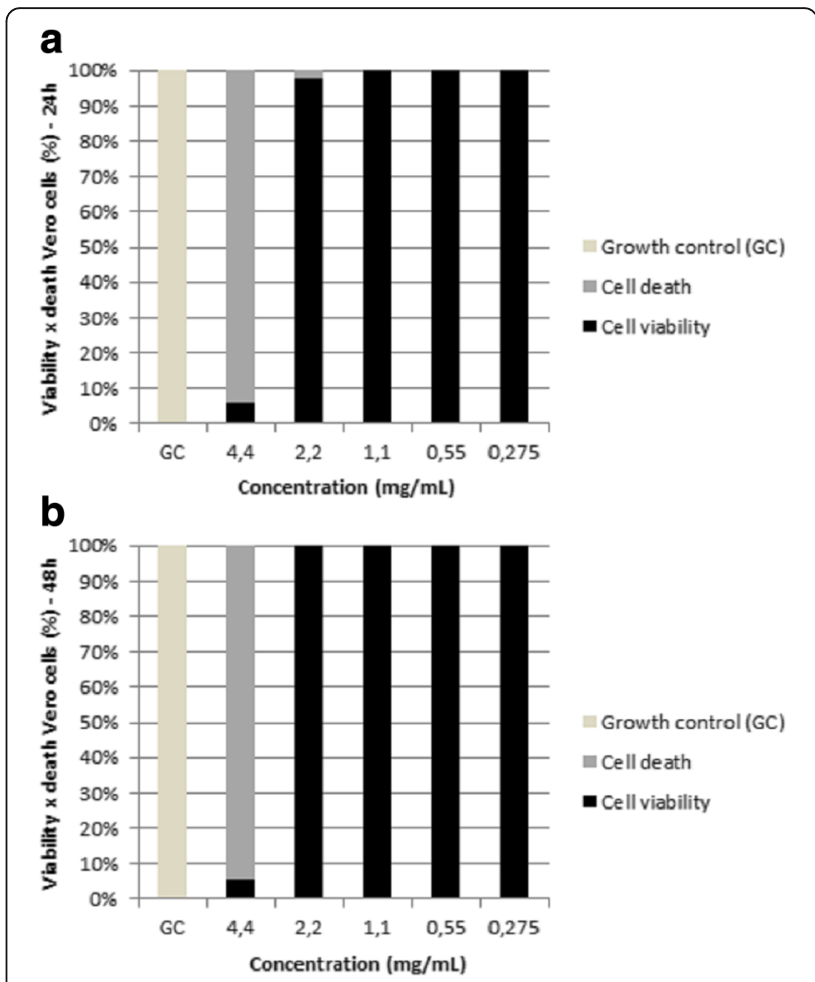

Fig. 1 Percentages Vero cell viability. Treated with differing concentrations of $M$. urundeuva essential oil after $24 \mathrm{~h} \mathrm{(a)} \mathrm{and} \mathrm{after}$ $48 \mathrm{~h}$ (b). GC: growth control

For the non-tumor cell strain HEK-293, we observed that the oil exerted no toxic effects. At $24 \mathrm{~h}$, cell proliferation occurred at levels near or above those of the untreated control cells. At $48 \mathrm{~h}$ we observed the same result. The statistical analysis showed that there was no difference between cell viability percentage in $24 \mathrm{~h}$ and $48 \mathrm{~h}$, and these were statistically the same, since the $p$ value obtained from the Wilcoxon test was $p=1$ $(p>0.05)$ (Fig. 3).

\section{Discussion}

Little has been reported on the antibacterial activity of Myracrodruon urundeuva essential oil [27]. However,

Table 2 Minimum Inhibitory Concentration (MIC) and Minimum Bactericidal Concentration (MBC) of the Myracrodruon urundeuva essential oil

\begin{tabular}{|c|c|c|c|c|}
\hline \multirow[b]{3}{*}{ Bacteria } & \multicolumn{4}{|c|}{ Concentrations (mg/mL) } \\
\hline & \multicolumn{2}{|c|}{ M. urundeuva essential oil } & \multicolumn{2}{|c|}{ Gentamicin } \\
\hline & MIC & MBC & MIC & $\mathrm{MBC}$ \\
\hline Staphylococcus aureus (ATCC 25923) & 0.220 & 0.220 & 0.004 & 0.004 \\
\hline Staphylococcus epidermidis (ATCC 12228) & 0.110 & 0.220 & 0.004 & 0.004 \\
\hline Escherichia coli (ATCC 25922) & 0.880 & 1.750 & 0.004 & 0.004 \\
\hline Pseudomonas aeruginosa (ATCC 27853) & 7.000 & 7.000 & 0.004 & 0.004 \\
\hline Salmonella Enteritidis (INCQS 500258) & 0.440 & 0.440 & 0.004 & 0.004 \\
\hline
\end{tabular}




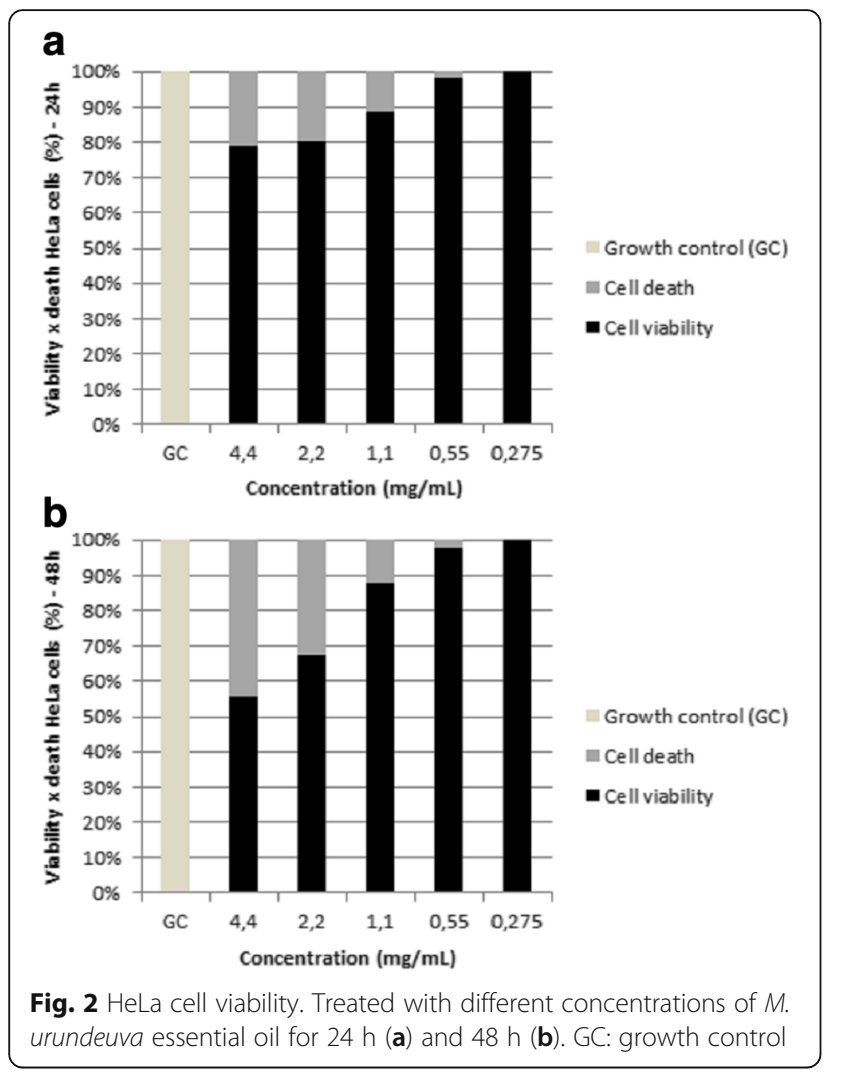

studies of other essential oils from the same plant (with different chemical compositions) have been tested against some of the bacteria herein tested. Among these, S. aureus [26, 35-37], E. coli [26, 36, 37], and P. aeruginosa [37], were inhibited by such extracts, showing the antimicrobial activity of $M$. urundeuva.

However, in this study, the M. urundeuva leaf essential oil showed antibacterial activity against all tested strains. Such activity is probably attributable to the terpenoids, since they represented a higher proportion of the constituents in the GC-MS and GC/FID analyses. Similarly, other studies attribute antimicrobial activity to these secondary metabolites due to being abundant constituents in these essential oils [16-20, 27, 28, 38].

This study presents $\alpha$-pinene $(87.85 \%)$ as the major constituent in $M$. urundeuva leaf essential oil. However, it is not known whether $\alpha$-pinene is chiefly responsible for the bactericidal action of the oil, or if one of the other terpenes promotes such action, since in other studies, the essential oils from $M$. urundeuva leaves have shown different terpene proportions from our results $[27,28,39,40]$. It is important to consider differences in the chemical composition of essential oils extracted from plants of the same species. These differences arise from factors such as geographic variation, climate, soil, planting modes, fertilizers used, time of collection, and the post collection processing and extraction techniques

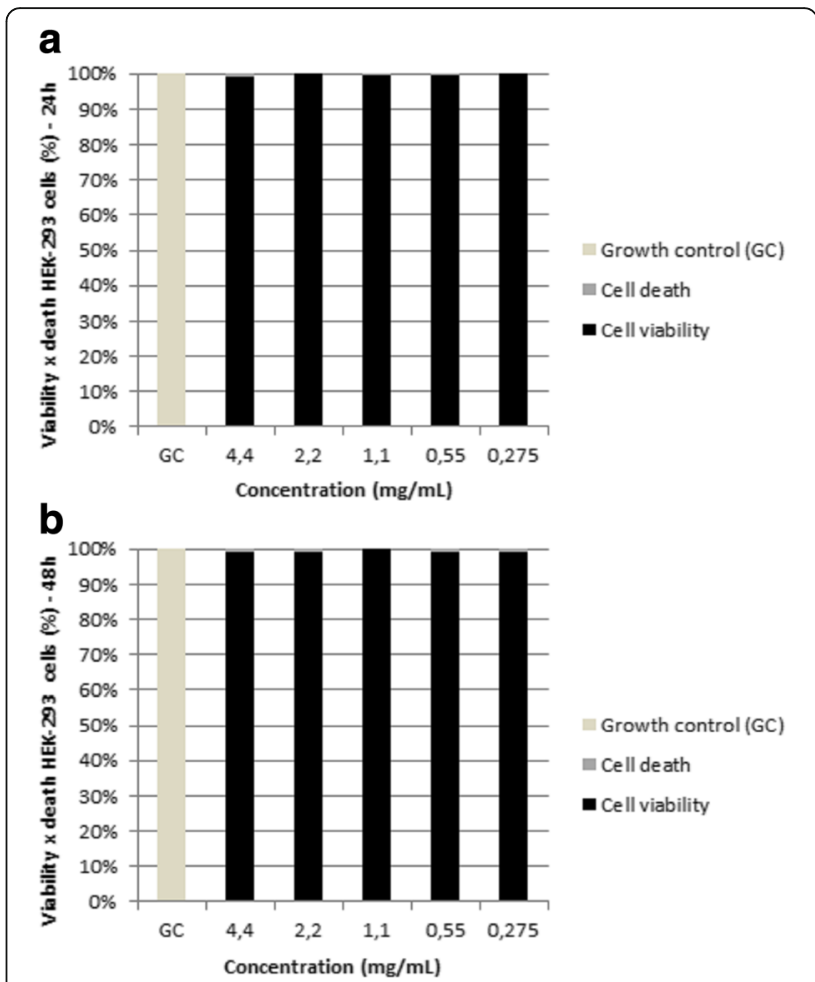

Fig. 3 HEK-293 cell viability. Treated with different concentrations of M. urundeuva essential oil for $24 \mathrm{~h}$ (a) and $48 \mathrm{~h}$ (b). GC: growth control

employed [41-44]. It is believed that the $M$. urundeuva essential oil's antibacterial activity is likely conferred by terpenes, since they are abundant in the composition.

Some papers support the hypothesis that $\alpha$-pinene is responsible for the antimicrobial action reported in the present study. In work by Leite et al. [45], this terpene was isolated and showed antibacterial activity against $S$. aureus and S. epidermidis. Other studies that identified $\alpha$-pinene as a major constituent in the composition of essential oils from plants other than M. urundeuva also observed antibacterial activity against Gram-negative and Gram-positive bacteria [46-49].

In the current study, we observed $M$. urundeuva essential oil's bactericidal action for all of the bacteria tested: Gram-positive (S. aureus and S. epidermidis) and Gramnegative (E. coli, $P$. aeruginosa and $S$. enteritidis). The MIC and MBC data show higher antibacterial activity against Gram-positive bacteria than Gram-negative bacteria. This is probably due to the greater complexity of the Gram-negative cell wall [50], which interferes with any direct action on the pathogen metabolism. Among the five strains tested, S. epidermidis (MIC $=0.11 \mathrm{mg} / \mathrm{mL}$ ) was found to be the most sensitive to M. urundeuva essential oil, showing even higher sensitivity than the other Gram positive bacteria, $S$. aureus $(\mathrm{MIC}=0.22 \mathrm{mg} / \mathrm{mL}$ ). For the three Gram-negative bacteria, $M$. urundeuva essential oil more strongly inhibited $S$. enteritidis $(\mathrm{MIC}=0.44 \mathrm{mg} / \mathrm{mL}$ ) 
compared to $E$. coli $(\mathrm{MIC}=0.88 \mathrm{mg} / \mathrm{mL})$ and $P$. aeruginosa ( $\mathrm{MIC}=7.0 \mathrm{mg} / \mathrm{mL})$. P. aeruginosa was the least sensitive to the essential oil, possibly due to the ability of $P$. aeruginosa to produce biofilm [51], which further complicates direct action of the aromatic oil component against the bacterial cell.

In addition to $M$. urundeuva, the literature reports studies that prove the effectiveness of essential oils obtained from other plants [52-59]. Although these other plants show similar or higher antibacterial activities than $M$. urundeuva, one should not underestimate its promising antibacterial effect.

However, some essential oils extracted from other plants exert weaker antimicrobial activity against the bacteria tested herein because of weaker inhibition of bacterial growth, higher MIC values, or a demonstrated bacterial resistance [60-68]. These results, when compared with those obtained in the present study, reveal the more promising antibacterial power of M. urundeuva essential oil, likely because it contains specific active components.

For HeLa cells, M. urundeuva oil shows increasing cytotoxicity over longer exposure times, indicating possible anticancer activity. For the Vero E6 strain, M. urundeuva oil cytotoxicity decreased with increasing exposure time, i.e., the greater the exposure time the lower the cytotoxic activity, and the higher the cell viability. This effect was also observed for the HEK-293 line, where cell viability was superior to both Vero strain readings. For the Vero E6 and HEK-293 strains, these results confirm that the essential oil is potentially non-cytotoxic to normal human and mammalian cells in general.

Literature data on $M$. urundeuva essential oil cellular toxicity are still scarce. However, some researchers have evaluated the toxicity of $M$. urundeuva oil, stimulating further research on their use as a source of medicinal products. In the study by Carvalho et al. [28] its essential oil showed low cytotoxicity for human erythrocytes. Work by Ferreira et al. [69] highlights the antiproliferative power of the methanolic extract obtained from $M$. urundeuva against HL-60 lines (leukemia) cancer, SF295 (glioblastoma), HCT-8 (colon), and MDA/MB-435 (melanoma) cells, indicating the possible antitumor effects of $M$. urundeuva extracts.

Despite the data obtained from these cell toxicity tests, additional in vitro assays are needed and will be conducted in the future, such as cytotoxicity against normal human cells originating from other tissues, and further investigation of its antitumor activity in fibroblasts and other neoplastic cells. Further testing is needed to prove the effectiveness of the oil in vivo so it can be considered pharmacologically viable. Finally, M. urundeuva oil showed significant antibacterial activity, notable antitumor effectiveness, and very low cell toxicity.

\section{Conclusion}

Essential oil extracted from the leaves of Myracrodruon urundeuva showed promising Gram-positive and Gramnegative antibacterial activity. Additionally, the in vitro cytotoxicity test results were satisfactory, since the oil was not toxic to human cells and displayed an antitumor effect, showing its potential as a reliable source for phyto-pharmaceutics in the future. Although further in vivo assays and in vitro toxicity studies are necessary in normal human cells to prove its efficacy and safety in pre-clinical use, the results obtained here for M. urundeuva essential oil are already promising from a pharmacological point of view and suggest future applications.

\section{Abbreviations \\ ATCC: American Type Culture Collection; BHI: Brain heart infusion; CFU: Colony-forming units; CTT: 2.3.5-triphenyl-tetrazolium chloride; DMEM: Dulbecco's modified Eagle's medium; FBS: Fetal bovine serum; GC: Growth control; GC-FID: Gas Chromatography-Flame Ionization Detector; GC-MS: Gas chromatography-mass spectrometry; INCQS: Instituto Nacional de Controle de Qualidade em Saúde; MBC: Minimum Bactericidal Concentration; MIC: Minimum Inhibitory Concentration; MTT: [3-(4.5- dimethylthiazolyl)-2.5-diphenyl-tetrazolium bromide]; NC: Negative control; PC: Positive control; Rl: Kovat's retention index}

\section{Acknowledgments}

This work was supported by grants from FAPERN (Fundação de Apoio à Pesquisa do RN), CNPQ (Conselho Nacional de Pesquisa), CAPES (Coordenação de Aperfeiçoamento de Pessoal de Nível Superior), UFRN (Federal University of Rio Grande do Norte) and by Paulo Roberto Medeiros de Azevedo, who performed the statistical analysis in this study.

\section{Funding}

FAPERN (Fundação de Apoio à Pesquisa do RN) provided funding for the study design and CAPES (Coordenação de Aperfeiçoamento de Pessoal de Nivel Superior) funded the work during its development.

Availability of data and materials

All the details of data and materials of this study are included in the manuscript.

\section{Authors' contributions}

IDRA, JVF and VSA conceived the experimental design; NCA and RMA performed extraction and phytochemical characterization of the essential oil; IDRA and VSA designed and performed the microbial assays; RFAJ, KJSF, ACVAG and RFAJ designed and performed cytotoxicity assays; IDRA, NCA and ACVAG wrote the paper. All authors read and approved the manuscript.

Ethics approval and consent to participate

Not applicable.

\section{Consent for publication}

Not applicable.

Competing interests

The authors declare that they have competing interests.

\section{Publisher's Note}

Springer Nature remains neutral with regard to jurisdictional claims in published maps and institutional affiliations.

\section{Author details}

${ }^{1}$ Centro de Biociências (CB), Departamento de Microbiologia e Parasitologia, Universidade Federal do Rio Grande do Norte (UFRN), Natal, RN 59072-970, Brazil. ${ }^{2}$ Centro de Ciências, Departamento de Química Orgânica e Inorgânica, Universidade Federal do Ceará (UFC), Fortaleza, CE 60021-940, Brazil. ${ }^{3}$ Centro de Biociências (CB), Departamento de Morfologia, Universidade Federal do 
Rio Grande do Norte (UFRN), Natal, RN 59072-970, Brazil. ${ }^{4}$ Centro de Ciências da Saúde (CCS), Departamento de Análises Clínicas e Toxicológicas, Universidade Federal do Rio Grande do Norte (UFRN), Natal, RN 59072-970, Brazil. ${ }^{5}$ Centro de Ciências Exatas e da Terra (CCET), Instituto de Química, Universidade Federal do Rio Grande do Norte (UFRN), Natal, RN 59072-970, Brazil. 'Instituto de Medicina Tropical (IMT), Universidade Federal do Rio Grande do Norte (UFRN), Natal, RN 59072-970, Brazil.

\section{Received: 18 January 2017 Accepted: 10 August 2017}

Published online: 22 August 2017

\section{References}

1. Veiga JAF, Pinto AC. Plantas Medicinais: cura segura? Quim Nova. 2005;28:519-28.

2. Alves TMA, Silva AF, Brandão M, Grandi TSM, Smânia EFA, Júnior AS, Zani $\mathrm{CL}$. Biological screening of Brazilian medicinal plants. Mem Inst Oswaldo Cruz. 2000;95:367-73.

3. Daglia M. Polyphenols as antimicrobial agents. Curr Opin Biotechnol. 2012;23:174-81

4. Alanis AD, Calzada F, Cervantes JA, Torres J, Ceballos GM. Antibacterial properties of some plants used in Mexican traditional medicine for the treatment of gastrointestinal disorders. J Ethnopharmacol. 2005;100:153-7.

5. D'Costa VM, King CE, Kalan L, Morar M, Sung WWL, Schwarz C, Froese D, Zazula G, Calmels F, Debruyne R. Antibiotic resistance is ancient. Nature. 2011:477:457-61.

6. Jalan R, Fernandez J, Wiest R, Schnabl B, Moreau R, Angeli P, Stadlbauer V, Gustot T, Bernardi M, Canton R. Bacterial infections in cirrhosis: a position statement based on the EASL special conference 2013. J Hepatol. 2014;60:1310-24.

7. Tacconelli E, Cataldo MA, Dancer SJ, Angelis G, Falcone M, Frank U, Kahlmeter G, Pan A, Petrosillo N, Rodríguez-Baño J. ESCMID guidelines for the management of the infection control measures to reduce transmission of multidrug-resistant gram-negative bacteria in hospitalized patients. Clin Microbiol Infect. 2014;20:1-55.

8. Sharifi-Rad J, Hoseini-Alfatemi SM, Sharifi-Rad M, da Silva JAT. Antibacterial, antioxidant, antifungal and anti-inflammatory activities of crude extract from Nitraria schoberi fruits. 3. Biotech. 2015;5:677-84.

9. Veras HNH, Rodrigues FFG, Colares AV, Menezes IRA, Coutinho HDM, Botelho MA, Costa JGM. Synergistic antibiotic activity of volatile compounds from the essential oil of Lippia sidoides and thymol. Fitoterapia. 2012;83:508-12.

10. Betoni JEC, Mantovani RP, Barbosa LN, di Stasi LC, Fernandes A. Synergism between plant extract and antimicrobial drugs used on Staphylococcus aureus diseases. Mem Inst Oswaldo Cruz. 2006;101:387-90.

11. Kumar AS, Venkateshwaran K, Vanitha J, Saravanan VS, Ganesh M, Vasudevan M, Sivakumar T. Synergistic activity of methanolic extract of Thespesia populnea (Malvaceae) flowers with oxytetracycline. Bangladesh J Pharmacol. 2008;4:13-6.

12. Duarte $A E$, Menezes IRA, Braga MFBM, Leite NF, Barros LM, Waczuk EP, Silva MAP, Boligon A, Rocha JBT, Souza DO, Kamdem JP, Coutinho HDM, Burger ME. Antimicrobial activity and Modulatory effect of essential oil from the leaf of Rhaphiodon echinus (Nees \& Mart) Schauer on some antimicrobial drugs. Molecules. 2016;21:743.

13. Da Silva ACR, Lopes PM, de Azevedo MMB, Costa DC, Alviano CS, Alviano DS. Biological activities of a-pinene and $\beta$-pinene enantiomers. Molecules. 2012;17:6305-16.

14. Bakkali F, Averbeck S, Averbeck D, Idaomar M. Biological effects of essential oils - a review. Food Chem Toxicol. 2008;46:446-75.

15. Edris AE. Pharmaceutical and therapeutic potentials of essential oils and their individual volatile constituents: a review. Phytother Res. 2007;21:308-23.

16. Xiong L, Peng C, Zhou QM, Wan F, Xie XF, Guo L, Li XH, He CJ, Dai O. Chemical composition and antibacterial activity of essential oils from different parts of Leonurus japonicus Houtt. Molecules. 2013;18:963-73.

17. Lang G, Buchbauer $G$. A review on recent research results (2008-2010) on essential oils as antimicrobials and antifungals. A review Flav Frag J. 2012;27:13-39.

18. Si W, Gong J, Tsao R, Zhou T, Yu H, Poppe C, Johnson R, Du Z. Antimicrobial activity of essential oils and structurally related synthetic food additives towards selected pathogenic and beneficial gut bacteria. J Appl Microb. 2006;100:296-305

19. Reichling J, Schnitzler P, Suschke U, Saller R. Essential oils of aromatic plants with antibacterial, antifungal, antiviral, and cytotoxic properties-an overview. Forsch Komplementmed. 2009;16:79-90.

20. Sousa OV, Del-Vechio-Vieira G, Alves MS, Araújo AAL, Pinto MAO, Amaral MPH, Rodarte MP, Kaplan MAC. Chemical composition and biological activities of the essential oils from Duguetia lanceolata St. Hil barks Molecules. 2012;17:11056-66.

21. Sylvestre M, Legault J, Dufour D, Pichette A. Chemical composition and anticancer activity of leaf essential oil of Myrica gale L. Phytomedicine. 2005; 12:299-304

22. Sylvestre M, Pichette A, Longtin A, Nagau F, Legault J. Essential oil analysis and anticancer activity of leaf essential oil of Croton flavens L. from Guadeloupe. J. Ethnopharmacol. 2006;103:99-102.

23. Nunes YRF, Fagundes M, Almeida HS, Veloso MDM. Aspectos ecológicos da Aroeira (Myracrodruon urundeuva Allemão - Anacardiaceae): Fenologia e germinação das sementes. R Árvore. 2008;32:233-43.

24. Alves PM, Queiroz LMG, Pereira JV, Pereira MSV. In vitro antimicrobial, antiadherent and antifungal activity of Brazilian medicinal plants on oral biofilm microorganisms and strains of the genus Candida. Rev Soc Bras Med Trop. 2009:42:222-4.

25. Menezes TEC, Delbem ACB, Brighenti FL, Okamoto AC, Júnior EGJ. Protective efficacy of Psidium cattleianum and Myracrodruon urundeuva aqueous extracts against caries development in rats. Pharm Bio. 2010;48:300-5.

26. Pinho L, Souza PNS, Sobrinho EM, Almeida AC, Martins ER. Atividade antimicrobiana de extratos hidroalcoólicos das folhas de alecrim-pimenta, aroeira, barbatimão, erva baleeira e do farelo da casca de pequi. Ciência Rural. 2012;42:326-31.

27. Figueredo FG, Lucena BFF, Tintino SR, Matias EFF, Leite NF, Andrade JC, Nogueira LFB, Morais EC, Costa JGM, Coutinho HDM, Rodrigues FFG. Chemical composition and evaluation of modulatory of the antibiotic activity from extract and essential oil of Myracrodruon urundeuva. Pharm Biol. 2014;52(5):560-5.

28. Carvalho CES, Sobrinho-Junior EPC, Brito LM, Nicolau LAD, Carvalho TP, Moura AKS, Rodrigues KAF, Carneiro SMP, Arcanjo DDR, Citó AMGL, Carvalho FAA. Anti-Leishmania activity of essential oil of Myracrodruon urundeuva (Engl.) Fr. All.: composition, cytotoxicity and possible mechanisms of action. Exp Parasitol. 2017;175:59-67.

29. Viana GSB, Bandeira MAM, Matos FJA. Analgesic and antiinflammatory effects of chalcones isolated from Myracrodruon urundeuva Allemão. Phytomedicine 2003, 10: 189-195.

30. Gottlieb OR, Magalhães MT. Modified distillation trap. Chemist Analyst. 1960:49:114

31. Adams RP. Identification of essential oil components by gas chromatography/mass spectroscopy. 4rd ed. Illinois: Allured Publishing Corporation; 2007.

32. M100-S26. Performance standards for antimicrobial susceptibility testing USA: Clinical and Laboratory Standards Institute; 2016.

33. Smânia JA, Valgas C, Souza SM, Smânia EFA. Screening methods to determine antibacterial activity of natural products. Braz J of Microbiology 2007:38:369-80.

34. Mosmann T. Rapid colorimetric assay for cellular growth and survival: Aplication to proliferation and cytotoxicity assays. J of Immunological Methods. 1983:65:55-63.

35. Silva CM, Mota FBC, Rodrigues MD, Alves OD, Maia VH. Crude extracts and semi-fractions from Myracrodruon urundeuva with antibacterial activity against American type culture collection (ATCC) strains of clinical relevance. J of Medicinal Plants Research. 2013;7:2407-13.

36. Jandú JJB, Silva LCN, Silva MV, Correia MTS. Antimicrobial activity and synergistic effects of an ethyl acetate fraction from methanol extract of Myracrodruon urundeuva bark. J of Medicinal Plants Research. 2015;9:641-6.

37. Sá RA, Gomes FS, Napoleão TH, Santos NDL, Melo CML, Gusmão NB, Coelho LCBB, Paiva PMG, Bieber LW. Antibacterial and antifungal activities of Myracrodruon urundeuva heartwood. Wood Sci Technol. 2009;43:85-95.

38. Sartoratto A, Machado ALM, Delarmelina C, Figueira GM, Duarte MCT, Rehder VLG. Composition and antimicrobial activity of essential oils from aromatic plants used in Brazil. Braz J Microbiol. 2004;35:275-80

39. Montanari RM, Barbosa LCA, Demuner AJ, Silva CJ, Andrade NJ, Ismail FMZ, Barbosa MCA. Exposure to Anacardiaceae volatile oils and their constituents induced lipid peroxidation whitin food-borne bacteria cells. Molecules. 2012; 17:9728-40.

40. Costa OB, Menezzi CHSD, Benedito LEC, Resck IS, Vieira RF, Bizzo HR. Essential oil constituents and yields from leaves of Blepharocalyx salicifolius (Kunt) O. Berg and Myracrodruon urundeuva (Allemão) collected during daytime. Int J of Forestry Res. 2014:2014:1-6.

41. Sefidkon F, Abbasi K, Jamzad Z, Ahmadi S. The effect of distillation methods and stage of plant growth on the essential oil content and composition of Satureja rechingeri Jamzad. Food Chem. 2007;100:1054-8. 
42. Asekun OT, Grierson DS, Afolayan AJ. Effects of drying methods on the quality and quantity of the essential oil of Mentha longifolia L. subsp. Capensis. Food Chem. 2007;101:995-8.

43. Apel MA, Sobral M, Henriques AT. Composição química do óleo volátil de Myrcianthes nativas da região sul do Brasil. Rev Bras Farmacogn. 2006;16:402-7.

44. Potzernheim MCL, Bizzo HL, Vieira RF. Análise dos óleos essenciais de três espécies de Piper coletadas na região do Distrito Federal (Cerrado) e comparação com óleos de plantas procedentes da região de Paraty, RJ (Mata Atlântica). Rev Bras Farmacogn. 2006;16:246-51.

45. Leite AM, Lima EO, Souza EL, Diniz MFFM, Trajano VN, Medeiros IA. Inhibitory effect of $\beta$-pinene, $\alpha$-pinene and eugenol on the growth of potential infectious endocarditis causing gram-positive bacteria. Braz J Pharm Sci. 2007;43(1):121-6.

46. Gachkar L, Yadegari D, Rezaei MB, Taghizadeh M, Astaneh SA, Rasooli I. Chemical and biological characteristics of Cuminum cyminum and Rosmarinus officinalis essential oils. Food Chem. 2007;102:898-904.

47. Lee JH, Yang HY, Lee HS, Hong SK. Chemical composition and antimicrobial activity of essential oil from cones of Pinus koraiensis. J Microbiol Biotechnol. 2008;18(3):497-502.

48. Imelouane B, Amhamdi H, Wathelet JP, Ankit M, Khedid K, El Bachiri A. Chemical composition and antimicrobial activity of essential oil of thyme (Thymus vulgaris) from eastern Morocco. Int J Agric Biol. 2009;11(2):205-8.

49. Nissen L, Zatta A, Stefanini I, Grandi S, Sgorbati B, Biavati B, Monti A. Characterization and antimicrobial activity of essential oils of industrial hemp varieties (Cannabis sativa L.). Fitoterapia. 2010;81:413-9.

50. Costerton JW, Ingram JM, Cheng KJ. Structure and function of the cell envelope of gram-negative bacteria. Bacteriol Rev. 1974;38:87-110.

51. Chiang P, Burrows LL. Biofilm formation by hyperpiliated mutants of Pseudomonas aeruginosa. J Bacteriol. 2003;185:2374-8.

52. Santos A, Paduan RH, Gazin ZC, Jacomassi E. D' Oliveira OS, Cortez DAG, Cortez LER. Determinação do rendimento e atividade antimicrobiana do óleo essencial de Cymbopogon citratus (DC) Stapf em função de sazonalidade e consorciamento. Rev. Bras. Farmaco. 2009;19:436-41.

53. Unlu M, Ergene E, Unlu GV, Zeytinoglu HS, Vural N. Composition, antimicrobial activity andin vitro cytotoxicity of essential oil from Cinnamomum zeylanicum Blume (Lauraceae). Food Chem Toxicol. 2010;48:3274-80.

54. Hsouna AB, Trigui M, Mansour RB, Jarraya RM, Damak M, Jaoua S. Chemical composition, cytotoxicity effect and antimicrobial activity of Ceratonia siliqua essential oil with preservative effects against Listeria inoculated in minced beef meat. Int J Food Microbiol. 2011;148:66-72.

55. Hu H, Zheng $\mathrm{X}, \mathrm{Hu} \mathrm{H}$. Chemical composition, antimicrobial, antioxidant and cytotoxic activity of the essential oil from the leaves of Acanthopanax leucorrhizus (Oliv.) harms. Environ Toxicol Pharmacol. 2012;34:618-23.

56. Wang W, Li N, Luo M, Zu Y, Efferth T. Antibacterial activity and anticancer activity of Rosmarinus officinalis $L$. essential oil compared to that of its main components. Molecules. 2012;17:2704-13.

57. Ye CL, Dai DH, Hu WL. Antimicrobial and antioxidant activities of the essential oil from onion (Allium cepa L.). Food Control. 2013;30:48-53.

58. Abdel-Reheem MAT, Oraby MM. Anti-microbial, cytotoxicity, and necrotic ripostes of Pimpinella anisum essential oil. Ann Agric Sci. 2015;60:335-40.

59. Hajlaoui H, Mighri H, Aouni M, Gharsallah N, Kadri A. Chemical composition and in vitro evaluation of antioxidant, antimicrobial, cytotoxicity and antiacetylcholinesterase properties of Tunisian Origanum majorana L. essential oil. Microb Pathog. 2016;95:86-94.

60. Rattanachaikunsopon P, Phumkhachorn P. Antimicrobial activity of basil (Ocimum basilicum) oil against Salmonella Enteritidis in Vitro and in food. Biosci Biotechnol Biochem. 2010;74:1200-4.

61. Yu JQ, Lei JC, Zhang XQ, Yu HD, Tian DZ, Liao ZX, Zou G. Anticancer, antioxidant and antimicrobial activities of the essential oil of Lycopus /ucidus Turcz. Var. Hirtus Regel. Food Chem. 2011;126:1593-8.

62. Bouzidi LE, Jamali CA, Bekkouche K, Hassani L, Wohlmuthc H, Leach D, Abbad A. Chemical composition, antioxidant and antimicrobial activities of essential oils obtained from wild and cultivated Moroccan Thymus species. Ind Crop Prod. 2013:43:450-6.

63. Rashid S, Rather AM, Shah WA, Bhat BA. Chemical composition, antimicrobial, cytotoxic and antioxidant activities of the essential oil of Artemisia indica Willd. Food Chem. 2013;138:693-700.

64. Qi XL, Li TT, Wei ZF, Guo N, Luo M, Wang W, Zu YG, Fu YJ, Peng X. Solventfree microwave extraction of essential oil from pigeon pea leaves [Cajanus cajan (L.) Millsp.] and evaluation of its antimicrobial activity. Ind Crop Prod. 2014;58:322-8
65. Shakeri A, Khakdan F, Soheili V, Sahebkar A, Rassam G, Asili J. Chemical composition, antibacterial activity, and cytotoxicity of essential oil from Nepeta ucrainica L. spp. Kopetdaghensis. Ind Crop Prod. 2014;58:315-21.

66. Kazemi M. Chemical composition and antimicrobial, antioxidant activities and anti-inflammatory potential of Achillea millefolium L., Anethum graveolens L., and Carum copticum L. essential oils. J of Herbal Medicine. 2015;5:217-22.

67. Fitsiou E, Mitropoulou G, Spyridopoulou K, Tiptiri-Kourpeti A, Vamvakias M, Bardouki H, Panayiotidis MI, Galanis A, Kourkoutas Y, Chlichlia K, Pappa A. Phytochemical profile and evaluation of the biological activities of essential oils derived from the Greek aromatic plant species Ocimum basilicum, Mentha spicata. Pimpinella anisum and Fortunella margarita Molecules. 2016;21:1069.

68. Petrelli R, Orsomando G, Sorci L, Maggi F, Ranjbarian F, Nya PCB, Petrelli D, Vitali LA, Lupidi G, Quassinti L, Bramucci M, Hofer A, Cappellacci L. Biological activities of the essential oil from Erigeron floribundus. Molecules. 2016;21:1065.

69. Ferreira PM, Farias DF, Viana MP, Souza TM, Vasconcelos IM, Soares BM, Pessoa C, Costa-Lotufo L, Moraes MO, Carvalho AFU. Study of the antiproliferative potential of seed extracts from northeastern Brazilian plants. Annals of the Brazilian Academy of Sciences. 2011;83:1045-58.

\section{Submit your next manuscript to BioMed Central and we will help you at every step:}

- We accept pre-submission inquiries

- Our selector tool helps you to find the most relevant journal

- We provide round the clock customer support

- Convenient online submission

- Thorough peer review

- Inclusion in PubMed and all major indexing services

- Maximum visibility for your research

Submit your manuscript at www.biomedcentral.com/submit
) Biomed Central 